\title{
Nalmefene: a new approach to the treatment of alcohol dependence [Corrigendum]
}

Paille F, Martini H. Substance Abuse and Rehabilitation

2014;5:87-94

On page 93, the Disclosure was listed as "The authors report no conflicts of interest in this work.", however it should have been "Francois Paille is consultant for Ethypharm and Lundbeck, received honoraria from Ethypharm and Lundbeck, speaker fees from Lundbeck and Merck Serono and travel grants from Lundbeck. Hervé Martini received travel grants from Reckitt-Benckiser and Lundbeck."

Substance Abuse and Rehabilitation is an international, peer-reviewed, open access journal publishing original research, case reports, editorials, reviews and commentaries on all areas of addiction and substance abuse and options for treatment and rehabilitation. The manuscript management system is completely online and includes a very quick and fair peer-review system. Visit http://www.dovepress.com/testimonials.php to read real quotes from published authors. submit your manuscript | www.dovepress.com

Dovepress

http://dx.doi.org// 0.2/47/SAR.S88450 